\title{
Human mesenchymal stem cells reduce the severity of acute lung injury in a sheep model of bacterial pneumonia
}

\author{
Sven Asmussen, ${ }^{1}$ Hiroshi Ito, ${ }^{1}$ Daniel L Traber, ${ }^{1}$ Jae W Lee, ${ }^{2}$ Robert A Cox, ${ }^{1}$ \\ Hal K Hawkins, ${ }^{1}$ Daniel F McAuley, ${ }^{2,3}$ David H McKenna, ${ }^{4}$ Lillian D Traber, ${ }^{1}$ \\ Hanjing Zhuo, ${ }^{2}$ Jennifer Wilson, ${ }^{2}$ David N Herndon, ${ }^{5}$ Donald S Prough, ${ }^{1}$ \\ Kathleen D Liu, ${ }^{2}$ Michael A Matthay, ${ }^{2}$ Perenlei Enkhbaatar ${ }^{1}$
}

- Additional material is published online only. To view please visit the journal online (http://dx.doi.org/10.1136/ thoraxjnl-2013-204980).

${ }^{1}$ Department of Anesthesiology, The University of Texas Medical Branch, Galveston, Texas, USA

${ }^{2}$ Departments of Medicine \& Anesthesiology, Cardiovascular Research Institute, The University of California San Francisco, San Francisco, California, USA

${ }^{3}$ Centre for Infection and Immunity, The Queen's University of Belfast, Belfast, Northern Ireland, UK ${ }^{4}$ Production Assistance in Cellular Therapy, University of Minnesota, Saint Paul, Minnesota, USA

${ }^{5}$ Shriners Hospital for Children, Galveston, Texas, USA

\section{Correspondence to} Dr Perenlei Enkhbaatar, Department of Anesthesiology, University of Texas Medical Branch, 301 University Boulevard, Galveston, Texas 77555-1102, USA: peenkhba@utmb.edu

$\mathrm{SA}$ and $\mathrm{HI}$ contributed equally.

Received 18 December 2013 Revised 25 April 2014 Accepted 8 May 2014 Published Online First 2 June 2014

\section{ABSTRACT}

Background Human bone marrow-derived mesenchymal stem (stromal) cells (hMSCs) improve survival in mouse models of acute respiratory distress syndrome (ARDS) and reduce pulmonary oedema in a perfused human lung preparation injured with Escherichia coli bacteria. We hypothesised that clinical grade hMSCs would reduce the severity of acute lung injury (ALI) and would be safe in a sheep model of ARDS.

Methods Adult sheep (30-40 kg) were surgically prepared. After 5 days of recovery, ALI was induced with cotton smoke insufflation, followed by instillation of live Pseudomonas aeruginosa $\left(2.5 \times 10^{11} \mathrm{CFU}\right)$ into both lungs under isoflurane anaesthesia. Following the injury, sheep were ventilated, resuscitated with lactated Ringer's solution and studied for $24 \mathrm{~h}$. The sheep were randomly allocated to receive one of the following treatments intravenously over $1 \mathrm{~h}$ in one of the following groups: (1) control, Plasmalyte A, $n=8$; (2) lower dose hMSCs, $5 \times 10^{6} \mathrm{hMSCs} / \mathrm{kg}, \mathrm{n}=7$; and (3) higher-dose hMSCs, $10 \times 10^{6} \mathrm{hMSCs} / \mathrm{kg}, \mathrm{n}=4$.

Results By $24 \mathrm{~h}$, the $\mathrm{PaO}_{2} / \mathrm{FiO}_{2}$ ratio was significantly improved in both hMSC treatment groups compared with the control group (control group: $\mathrm{PaO}_{2} / \mathrm{FiO}_{2}$ of 97 $\pm 15 \mathrm{~mm} \mathrm{Hg}$; lower dose: $288 \pm 55 \mathrm{~mm} \mathrm{Hg}(p=0.003)$; higher dose: $327 \pm 2 \mathrm{~mm} \mathrm{Hg}(p=0.003))$. The median lung water content was lower in the higher-dose hMSCtreated group compared with the control group (higher dose: $5.0 \mathrm{~g}$ wet/g dry [IQR 4.9-5.8] vs control: $6.7 \mathrm{~g}$ wet/g dry [IQR 6.4-7.5] ( $p=0.01))$. The hMSCs had no adverse effects.

Conclusions Human MSCs were well tolerated and improved oxygenation and decreased pulmonary oedema in a sheep model of severe ARDS.

Trail registration number: NCT01775774 for Phase 1. NCT02097641 for Phase 2.

\section{INTRODUCTION}

The acute respiratory distress syndrome (ARDS) is a common cause of acute respiratory failure and is often caused by pneumonia and/or sepsis. ${ }^{1-3}$ ARDS is characterised by severe pulmonary oedema, leading to arterial hypoxaemia $\left(\mathrm{PaO}_{2}\right)$ $\left.\mathrm{FiO}_{2}<300 \mathrm{~mm} \mathrm{Hg}\right) .{ }^{4}$ Advances have been made in understanding the pathophysiology of ARDS, but therapies remain limited. Supportive care with lung

\section{Key messages}

What is the key question?

- Will intravenous delivery of bone marrow-derived human mesenchymal stem (stromal) cells reduce the severity of lung injury in a clinically relevant $24 \mathrm{~h}$ sheep model of severe pneumonia-related acute respiratory distress syndrome (ARDS)?

What is the bottom line?

- Treatment with human mesenchymal stem (stromal) cells reduced the severity of inhalational and bacterial inoculation induced lung injury as measured by improved oxygenation and decrease of extravascular lung water without adverse effects on haemodynamics.

\section{Why read on?}

- Because this preclinical study provides additional data to support the potential value of testing human bone marrow-derived mesenchymal stem (stromal) cells in patients with moderate to severe ARDS.

protective ventilation, ${ }^{5}$ prone ventilation ${ }^{6}$ and a conservative fluid management strategy ${ }^{7}$ have improved clinical outcomes, but no specific therapy has improved survival. Thus, new treatments are needed.

In this regard, cell-based therapies may be promising for treatment of patients with ARDS. Bone marrow-derived mesenchymal stem (stromal) cells (MSCs) have shown therapeutic value in preclinical studies of myocardial infarction, ${ }^{8}$ diabetes, ${ }^{9}$ sepsis, ${ }^{10}$ hepatic failure, ${ }^{11}$ acute renal failure ${ }^{12}$ and acute lung injury (ALI). ${ }^{13}$ Work from our laboratory demonstrated that intravenously administered clinical grade, allogeneic human bone marrow-derived mesenchymal stem cells (hMSCs) restored alveolar fluid clearance to a normal level and decreased inflammation in an ex vivo isolated human lung preparation injured with live bacteria. ${ }^{14}$ We also reported that intravenous hMSCs increased survival 
in a rodent model of gram-negative peritoneal sepsis ${ }^{15}$ and in a mouse model of pneumonia. ${ }^{16}$

In the present study, we hypothesised that clinical grade hMSCs would reduce the severity of lung injury and would be well tolerated in a sheep model of ARDS induced by cotton smoke inhalation and instillation of live Pseudomonas aeruginosa into both lungs.

\section{MATERIALS AND METHODS}

This study was approved by the Institutional Animal Care and Use Committee of the University of Texas Medical Branch and conducted in compliance with the guidelines of the National Institute of Health and the American Physiological Society for the care and use of laboratory animals.

\section{Surgical procedures}

Adult sheep were surgically prepared 5-7 days before the experiment. The surgical protocol has been described in previous studies. ${ }^{17} 18$ Briefly, under isoflurane anaesthesia (Aestiva/5, Compact 7100, Tec 7 vaporizer, Datex Ohmeda, Madison, Wisconsin, USA) administered via endotracheal tube, the right femoral artery was cannulated for arterial access (Intracath, 16GA, 24IN, Becton Dickinson, Sandy, Utah, USA) and a thermodilution catheter (Swan Ganz, model 131F7, Baxter, Edwards Division, Irvine, California, USA) was introduced through the right common jugular vein into the pulmonary artery. A catheter (Duralastic Silicone Tubing DT08, 0.062 in. ID, Allied Biomedical, Paso Robles, California, USA) was also positioned in the left atrium through the fifth intercostal space. To determine pulmonary transvascular fluid flux (lung lymph flow), a thoracotomy in the sixth intercostal space was performed and the efferent vessel of the caudal mediastinal lymph node was cannulated with Silastic medical grade tubing $(0.025$ in. ID, Dow Corning, Midland, Michigan, USA). Following the operative procedures, sheep were awakened and the catheters were connected to monitors through pressure transducers. During the 5-day recovery period, the condition of the sheep was checked three times daily to ensure good recovery as demonstrated by lack of fever, appropriate eating and drinking, and good physical appearance.

\section{Experimental protocol}

After 5 days of recovery, baseline values were obtained and a tracheostomy was done under ketamine/isoflurane anaesthesia. Smoke inhalation injury was produced by insufflation of cotton smoke as previously described. ${ }^{19}{ }^{20}$ Four sets of 12 breaths of smoke were delivered. Following the inhalation injury, P. aeruginosa (American Type Culture Collection) was instilled through a bronchoscope (Model PF-P40, Olympus America Inc., Melville, NY). The $P$. aeruginosa (strain 12-4-4) had been cultured overnight and centrifuged at $2000 \mathrm{rpm}$ for $15 \mathrm{~min}$. The bacteria were mixed with saline and their numbers adjusted to $\sim 2.5 \times 10^{11} \mathrm{CFU}$ in $30 \mathrm{~mL}$ solution. Aliquots $(10 \mathrm{~mL})$ of the bacterial mixture were instilled into the right middle, right lower and left lower lobes $(30 \mathrm{~mL}$ total). ${ }^{19} 20$ After the injury, the sheep were ventilated (Servo Ventilator 300C, Siemens-Elema, Sweden) with positive end-expiratory pressure (PEEP) of $5 \mathrm{~cm} \mathrm{H}_{2} \mathrm{O}$ and a tidal volume of $15 \mathrm{~mL} / \mathrm{kg}$ throughout the $24 \mathrm{~h}$ experimental period. The inspiratory concentration of $\mathrm{O}_{2}$ was maintained at $100 \%$ for the first $3 \mathrm{~h}$ following injury and adjusted thereafter according to blood gas analysis. The respiratory rate was initially set at $20 / \mathrm{min}$, and it was adjusted according to arterial $\mathrm{CO}_{2}$ concentration. All sheep received maintenance intravenous fluid during the study period, initially with lactated Ringer's solution at $4 \mathrm{~mL} / \mathrm{kg} / \mathrm{h}$, after which the infusion rate was adjusted to maintain the haematocrit close to baseline levels $( \pm 3 \%)$.

\section{Control and hMSC-treated groups}

Two or three sheep were injured at one time and then studied simultaneously. After injury, each sheep was randomly allocated to one of three groups ${ }^{1}$ : control (treated with PlasmaLyte A only, $\mathrm{n}=8)^{2}$; lower dose hMSCs (treated with $5 \times 10^{6} / \mathrm{kg}$ hMSCs, n=7); and ${ }^{3}$ higher dose hMSCs (treated with $10 \times 10^{6}$, kg hMSCs, n=4). Each experimental group always included one control sheep. Clinical grade hMSCs were obtained from the NHLBI Production Assistance for Cellular Therapies at the University of Minnesota. Prior to administration, the cryopreserved hMSCs were thawed in a water bath, washed with PlasmaLyte A and centrifuged to remove the DMSO and cell debris in the supernatant. They were then resuspended in PlasmaLyte A and counted prior to infusion. The cells were administered intravenously over $1 \mathrm{~h}$ via central line, starting $1 \mathrm{~h}$ after injury.

\section{Measurements}

Several cardiopulmonary variables were measured continuously, including pulmonary arterial, central venous, systemic arterial and left atrial pressures. Cardiac output was measured by thermodilution technique using a cardiac output computer $\left(\mathrm{COM}-1^{\mathrm{TM}}\right.$, Baxter, Edward Division). Peak airway and pause airway pressures (similar to plateau airway pressure in patients ventilated with volume control ventilation) were measured hourly. Arterial blood gases were analysed at multiple time points (GEM Premier 3000, Instrumental Laboratory, Lexington, Massachusetts, USA). Lymph flow and lymph and plasma protein concentrations were measured hourly from hours 1 through 6, and every third hour thereafter. It was assumed that lymph flow remained constant during the $3 \mathrm{~h}$ intervals. The pulmonary transvascular fluid flux was evaluated every $3 \mathrm{~h}$ based on the lung lymph flow measurements. ${ }^{17} 18$ Systemic vascular resistance index (SVRI) was calculated using standard equations. Urine output was measured every $3 \mathrm{~h}$.

\section{Chemistry measurements}

Serum BUN, creatinine, ALT, AST, lactate and glucose were measured at baseline, 12 and $24 \mathrm{~h}$.

\section{Prespecified criteria for euthanasia}

Systolic blood pressure $<50 \mathrm{~mm} \mathrm{Hg}$, heart rate $<40$ beats per minute over $1 \mathrm{~h}$, arterial $\mathrm{PaO}_{2}<50 \mathrm{~mm} \mathrm{Hg}$ at $\mathrm{FiO}_{2}=1.0$ over $1 \mathrm{~h}$ or an arterial $\mathrm{PaCO}_{2}>90 \mathrm{~mm} \mathrm{Hg}$ were prespecified as criteria for euthanasia. Sheep that did not require euthanasia prior to the end of the experimental period were sacrificed under deep anaesthesia $24 \mathrm{~h}$ after injury.

\section{Postmortem bronchoalveolar lavage}

A modified 14 French Foley catheter was wedged in a subsegmental division of the left lower lobe, and $40 \mathrm{~mL}$ of room temperature normal saline was instilled and the lavage fluid was aspirated. Unspun samples were used to determine the bacterial and neutrophil counts (Hemavet HV950FS, Drew Scientific, Inc., Oxford, Connecticut, USA).

\section{Postmortem lung wet-to-dry weight ratio}

The right lung and the upper half of the left lower lobe were used for determination of bloodless wet-to-dry weight ratio. ${ }^{21}$ 


\section{Statistical analyses}

Bivariate analysis was used for baseline data. Continuous variables are expressed as mean $\pm \mathrm{SE}$ and compared using one-way ANOVA tests with Bonferroni adjustments for multiple comparisons. Wet-to-dry weight ratios and bacterial and neutrophil counts in BAL fluid are presented as median with IQRs; they were compared using Kruskal-Wallis one-way analysis of variance, followed by Wilcoxon-Mann-Whitney tests with Bonferroni adjustments because they were not normally distributed.

For variables measured repeatedly over $24 \mathrm{~h}$, the data are presented as mean and SEs at different time points, and include available data from the four sheep that expired prior to $24 \mathrm{~h}$. To assess the impact of hMSC treatment on each measurement at the $24 \mathrm{~h}$ time point, analyses of covariance (ANCOVA) was performed, controlling for the baseline level. Only the 15 sheep that survived the full $24 \mathrm{~h}$ were included in the ANCOVA analyses at $24 \mathrm{~h}$. Furthermore, a generalised estimating equation (GEE) approach was used to test the impact of hMSC treatment over time, taking repeated measurements into account and using an exchangeable correlation matrix with robust variance estimator. An interaction term with treatment group and time was introduced into the full model and was removed for $\mathrm{p}$ values $>0.05$. A two-sided $\mathrm{p}$-value $<0.05$ was considered statistically significant.

\section{RESULTS}

There were no differences among the three study groups in any of the variables at baseline.

\section{Mortality}

Four sheep required euthanasia by the prespecified criteria before the end of $24 \mathrm{~h}$, including 2 of 8 control sheep (at $12 \mathrm{~h}$ and $15 \mathrm{~h}$ ), 1 of 7 lower-dose hMSC-treated sheep (at 18h) and 1 of 4 higher-dose hMSC-treated sheep (at $21 \mathrm{~h}$ ).

\section{Systemic haemodynamics}

Heart rate increased in all three groups after injury compared to baseline (figure 1A). At $24 \mathrm{~h}$, sheep treated with higher-dose hMSCs had an attenuated increase in heart rate compared with control sheep $(p=0.01)$. In the 15 sheep alive at $24 \mathrm{~h}$, systemic blood pressure (mean) was higher in sheep treated with higherdose hMSCs at $24 \mathrm{~h}$ compared with controls $(\mathrm{p}=0.05)$.
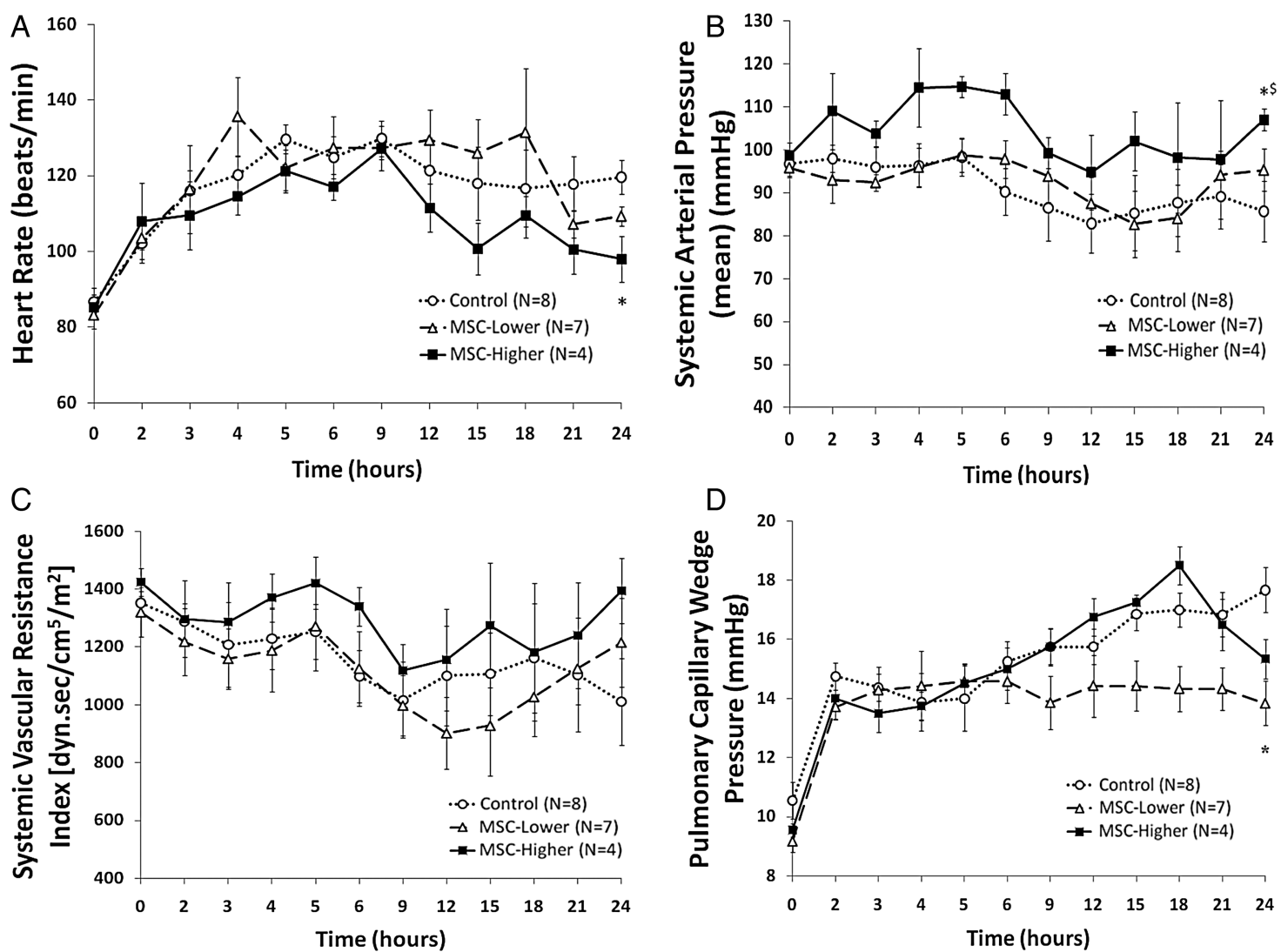

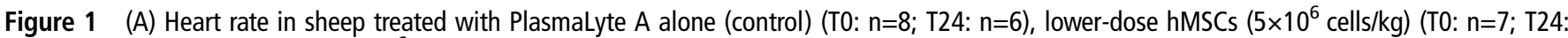
$n=6)$ and higher-dose hMSCs $\left(10 \times 10^{6}\right.$ cells $\left./ \mathrm{kg}\right)(T 0: n=4 ; T 24: n=3) .{ }^{*} p=0.01$ in the higher-dose hMSC group vs the control group at $24 \mathrm{~h}$ by ANCOVA. There were no significant differences among the treatment groups by the GEE. Data are expressed as mean \pm SEM. (B) Systemic arterial blood pressure (MAP) (mean) in sheep treated with PlasmaLyte A alone (control) (T0: $n=8 ; T 24: n=6)$, lower-dose $h M S C s\left(5 \times 10^{6}\right.$ cells/kg) (T0: $n=7$; T24: $n=6)$ and higher-dose hMSCs $\left(10 \times 10^{6}\right.$ cells $\left./ \mathrm{kg}\right)(T 0: n=4 ; T 24: n=3) .{ }^{*} p=0.004$ in the higher-dose hMSC group vs the control group at $24 \mathrm{~h}$ by ANCOVA. ${ }^{\$} p<0.05$ in the higher-dose hMSC group vs the control group during the $24 \mathrm{~h}$ period by the GEE. There was no significant difference between the lower-dose hMSC group and the control group by the GEE. Data are expressed as mean \pm SEM. (C) Systemic vascular resistance index (SVRI in sheep treated with PlasmaLyte A alone (control) (T0: $n=8 ; T 24: n=6)$, lower-dose hMSCs $\left(5 \times 10^{6}\right.$ cells/kg) (T0: $\left.n=7 ; T 24: n=6\right)$ and higher-dose hMSCs $\left(10 \times 10^{6}\right.$ cells/kg) (TO: $\left.n=4 ; T 24: n=3\right)$. No difference was found among the three groups at $24 \mathrm{~h}$ by ANCOVA or during the $24 \mathrm{~h}$ by the GEE. Data are expressed as mean \pm SEM. (D) Pulmonary capillary wedge pressure (PCWP) in sheep treated with PlasmaLyte A alone (control) (T0: $n=8 ;$ T24: $n=6)$, lower-dose hMSCs $\left(5 \times 10^{6}\right.$ cells $\left./ \mathrm{kg}\right)(T 0: n=7 ; T 24: n=6)$ and higher-dose hMSCs $\left(10 \times 10^{6}\right.$ cells/kg) (T0: $\left.n=4 ; T 24: n=3\right)$. $\mathrm{p}=0.007$ in lower-dose hMSC-treated sheep compared with control sheep by ANCOVA at $24 \mathrm{~h}$. There were no significant differences among the treatment groups by the GEE. Data are expressed as mean \pm SEM. 
Table 1 Cardiac output, haematocrit and arterial $\mathrm{pH}$ in the three sheep groups over $24 \mathrm{~h}$

\begin{tabular}{|c|c|c|c|c|c|c|c|c|c|c|}
\hline Parameter & Group & Baseline & 3 & 6 & 9 & 12 & 15 & 18 & 21 & 24 \\
\hline Cardiac output & $\begin{array}{l}\text { Control } \\
\text { Lower dose } \\
\text { Higher dose }\end{array}$ & $\begin{array}{l}5.37 \pm 0.1 \\
5.64 \pm 0.4 \\
5.25 \pm 0.2\end{array}$ & $\begin{array}{l}6.07 \pm 0.4 \\
6.10 \pm 0.5 \\
6.04 \pm 0.5\end{array}$ & $\begin{array}{l}5.94 \pm 0.2 \\
6.65 \pm 0.4 \\
6.24 \pm 0.5\end{array}$ & $\begin{array}{l}6.14 \pm 0.3 \\
7.05 \pm 0.5 \\
6.54 \pm 0.6\end{array}$ & $\begin{array}{l}5.69 \pm 0.4 \\
7.25 \pm 0.6 \\
6.04 \pm 0.5\end{array}$ & $\begin{array}{l}5.50 \pm 0.4 \\
6.55 \pm 0.6 \\
6.03 \pm 0.6\end{array}$ & $\begin{array}{l}5.77 \pm 0.6 \\
6.49 \pm 0.5 \\
6.00 \pm 0.4\end{array}$ & $\begin{array}{l}6.15 \pm 0.6 \\
6.11 \pm 0.3 \\
5.45 \pm 0.2\end{array}$ & $\begin{array}{l}6.10 \pm 0.5 \\
5.95 \pm 0.5 \\
5.56 \pm 0.3\end{array}$ \\
\hline Haematocrit & $\begin{array}{l}\text { Control } \\
\text { Lower dose } \\
\text { Higher dose }\end{array}$ & $\begin{array}{l}26.6 \pm 0.7 \\
25.3 \pm 1.0 \\
28.4 \pm 0.4\end{array}$ & $\begin{array}{l}30.3 \pm 0.9 \\
26.1 \pm 1.3^{*} \\
29.0 \pm 0.0\end{array}$ & $\begin{array}{l}30.3 \pm 1.1 \\
28.3 \pm 1.5 \\
30.8 \pm 0.5\end{array}$ & $\begin{array}{l}29.1 \pm 1.0 \\
26.7 \pm 1.1 \\
30.0 \pm 0.0\end{array}$ & $\begin{array}{l}29.3 \pm 1.3 \\
27.3 \pm 1.2 \\
30.8 \pm 1.7\end{array}$ & $\begin{array}{l}30.6 \pm 1.6 \\
28.3 \pm 0.8 \\
29.3 \pm 0.6\end{array}$ & $\begin{array}{l}29.5 \pm 0.8 \\
28.9 \pm 3.0 \\
29.5 \pm 0.3\end{array}$ & $\begin{array}{l}27.5 \pm 0.3 \\
25.8 \pm 1.4 \\
29.0 \pm 0.4\end{array}$ & $\begin{array}{l}28.0 \pm 0.5 \\
25.5 \pm 1.5 \\
28.7 \pm 0.9\end{array}$ \\
\hline Arterial pH & $\begin{array}{l}\text { Control } \\
\text { Lower dose } \\
\text { Higher dose }\end{array}$ & $\begin{array}{l}7.50 \pm 0.01 \\
7.48 \pm 0.02 \\
7.50 \pm 0.01\end{array}$ & $\begin{array}{l}7.55 \pm 0.02 \\
7.58 \pm 0.02 \\
7.57 \pm 0.02\end{array}$ & $\begin{array}{l}7.56 \pm 0.03 \\
7.56 \pm 0.01 \\
7.55 \pm 0.01\end{array}$ & $\begin{array}{l}7.54 \pm 0.03 \\
7.51 \pm 0.02 \\
7.52 \pm 0.02\end{array}$ & $\begin{array}{l}7.50 \pm 0.04 \\
7.52 \pm 0.01 \\
7.52 \pm 0.01\end{array}$ & $\begin{array}{l}7.50 \pm 0.04 \\
7.50 \pm 0.02 \\
7.50 \pm 0.00\end{array}$ & $\begin{array}{l}7.52 \pm 0.02 \\
7.47 \pm 0.05 \\
7.48 \pm 0.04\end{array}$ & $\begin{array}{l}7.53 \pm 0.03 \\
7.44 \pm 0.05 \\
7.50 \pm 0.07\end{array}$ & $\begin{array}{l}7.53 \pm 0.03 \\
7.47 \pm 0.02 \\
7.53 \pm 0.02\end{array}$ \\
\hline
\end{tabular}

Data are expressed as mean \pm SEM.

${ }^{*} p=0.02$ compared with control sheep by ANCOVA. Control: $n=8$ for $0-12 h ; n=7$ for $15 h$; $n=6$ for $18-24 h$. Lower dose: $n=7$ for $0-18 h$; $n=6$ for $2124 h$. Higher dose: $n=4$ for $0-21 \mathrm{~h} ; \mathrm{n}=3$ for $24 \mathrm{~h}$.

Systemic blood pressure in the high-dose group was also higher over the entire $24 \mathrm{~h}$ compared with controls $(p=0.004)$ (figure 1B). The cardiac output did not differ among the three groups during the experimental period (table 1). Systemic vascular resistance index (figure 1C) was not different among the three groups. At $24 \mathrm{~h}$, the pulmonary capillary wedge pressure (figure 1D) was lower only in the lower-dose hMSC-treated sheep $(p=0.007)$. Except for one time point, the haematocrit was not different among the three groups (table 1). There were also no differences in arterial $\mathrm{pH}$ levels after the injury among the three groups (table 1).

\section{Pulmonary haemodynamics}

The mean pulmonary arterial pressure increased after injury in all three groups and remained elevated throughout the study period (figure 2A). At $24 \mathrm{~h}$, the surviving sheep treated with either lower or higher dose hMSCs had significantly attenuated increases in pulmonary arterial pressure compared with sheep in the control group $(p<0.001$ and $p=0.008$, respectively). Pulmonary arterial pressure was also lower during the $24 \mathrm{~h}$ period in the high-dose hMSC-treated sheep compared with the control sheep $(p=0.04)$ (figure $2 \mathrm{~A})$. Pulmonary vascular resistance index (figure $2 \mathrm{~B}$ ) was not different at $24 \mathrm{~h}$ or during the experimental period.

\section{Airway pressures}

The peak and pause airway pressures increased in all three groups compared with baseline, but there were no differences among the groups over time or at $24 \mathrm{~h}$ (figure $3 \mathrm{~A}$ and $\mathrm{B}$ ). While peak airway pressures were numerically lowest in the higherdose hMSC group, this difference did not quite reach significance $(p=0.08)$.

\section{Lung lymph flow and protein balance}

Lymph flow and lymph protein flux increased in all groups but there were no statistical differences among the groups (see online supplementary material).

\section{Total fluid balance}

The control sheep accumulated $3 \mathrm{~L}$ over $24 \mathrm{~h}$ and sheep treated with lower dose hMSCs accumulated $2.5 \mathrm{~L}$, while sheep treated with the higher dose hMSCs had an even fluid balance (figure 4).
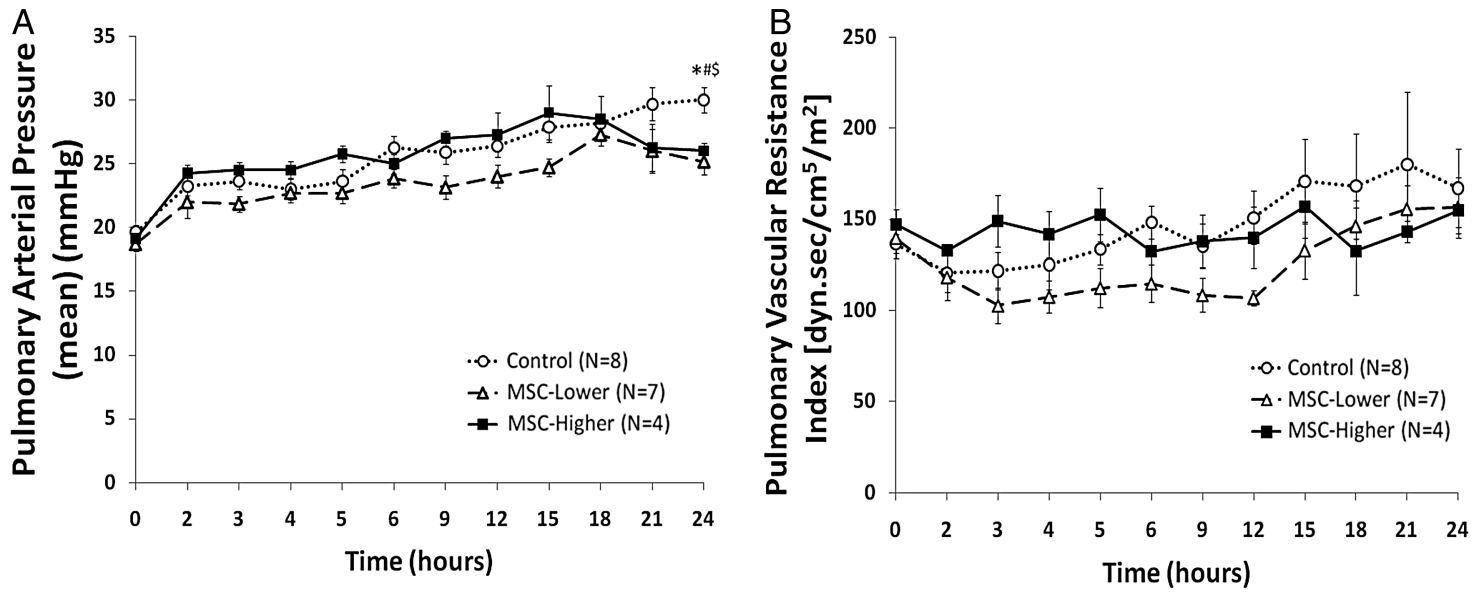

Figure 2 (A) Pulmonary arterial pressure (PAP) in sheep treated with PlasmaLyte A alone (control) (T0: $n=8 ; T 24: n=6)$, lower-dose hMSCs $\left(5 \times 10^{6}\right.$ cells $\left./ \mathrm{kg}\right)($ TO: $n=7 ;$ T24: $n=6)$ and higher-dose hMSCs $\left(10 \times 10^{6}\right.$ cells $\left./ \mathrm{kg}\right)(T 0: n=4 ; T 24: n=3)$. ${ }^{*} p=0.008$ in higher-dose hMSC-treated sheep compared with control sheep by ANCOVA at $24 \mathrm{~h}$. ${ }^{\#} \mathrm{p}<0.001$ in lower-dose hMSC-treated sheep compared with control sheep by ANCOVA at $24 \mathrm{~h}$. $\$ p=0.04$ in the higher-dose hMSC group vs the control group during the $24 \mathrm{~h}$ period by the GEE. There was no significant difference between the lower-dose hMSC group and the control group by the GEE. Data are expressed as mean \pm SEM. (B) Pulmonary vascular resistance index (PVRI) in sheep treated with PlasmaLyte A alone (control) (T0: $n=8 ; T 24: n=6)$, lower-dose hMSCs $\left(5 \times 10^{6}\right.$ cells/kg) (T0: $n=7 ;$ T24: $\left.n=6\right)$ and higher-dose hMSCs $\left(10 \times 10^{6}\right.$ cells $\left./ \mathrm{kg}\right)(T 0: n=4 ; T 24: n=3)$. No difference was found among the three groups at $24 \mathrm{~h}$ by ANCOVA. There were no significant differences among the treatment groups by the GEE. Data are expressed as mean \pm SEM. 

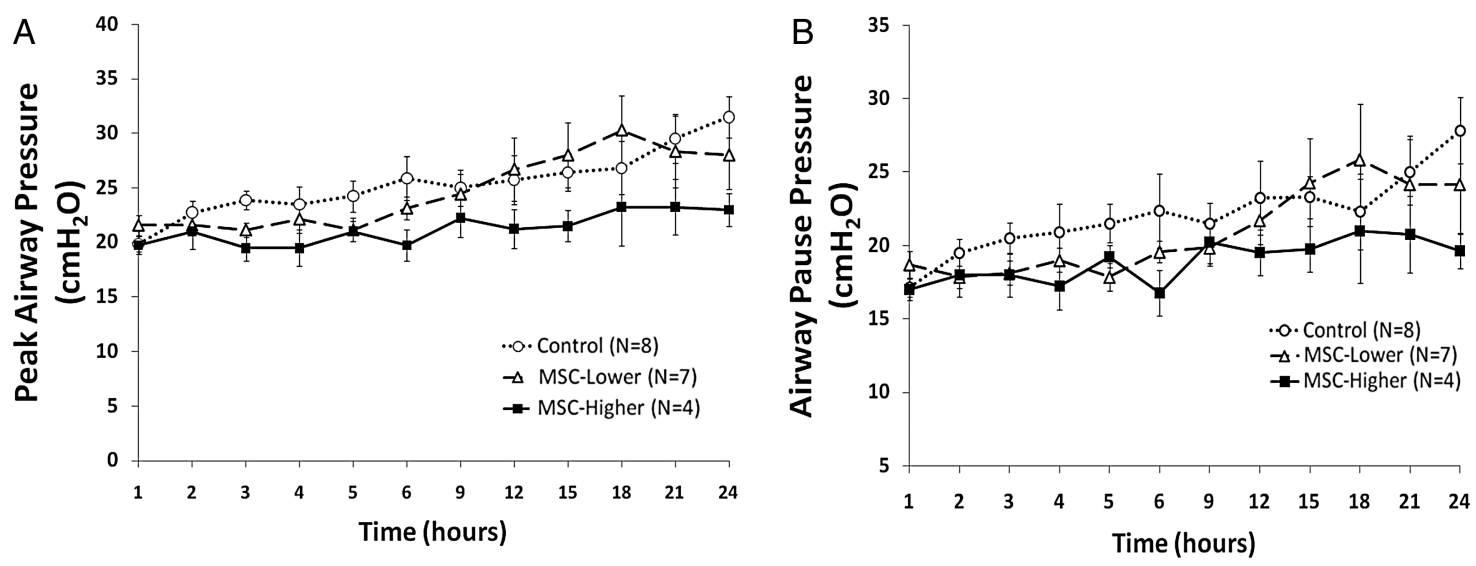

Figure 3 (A) Peak airway pressure in sheep treated with PlasmaLyte A alone (control) (T0: $n=8 ; T 24: n=6)$, lower-dose $h M S C s\left(5 \times 10^{6}\right.$ cells/kg) (T0: $n=7 ; T 24: n=6)$ and higher-dose hMSCs $\left(10 \times 10^{6}\right.$ cells/kg) (T0: $\left.n=4 ; T 24: n=3\right)$. There were no statistical differences in the lower-dose and higher-dose hMSC-treated sheep vs control sheep by ANCOVA at $24 \mathrm{~h}$. There were no significant differences among the treatment groups by the GEE. Data are expressed as mean \pm SEM. (B) Pause airway pressure in sheep treated with PlasmaLyte $A$ alone (control) (T0: $n=8 ; T 24: n=6)$, lower-dose hMSCs $\left(5 \times 10^{6}\right.$ cells/kg) (T0: $n=7 ;$ T24: $\left.n=6\right)$ and higher-dose hMSCs $\left(10 \times 10^{6}\right.$ cells/kg) (T0: $n=4 ;$ T24: $\left.n=3\right)$. There were no differences in the lower and higher hMSC-treated groups vs the control group at $24 \mathrm{~h}$ by ANCOVA or during the $24 \mathrm{~h}$ experiment period by the GEE. Data are expressed as mean $\pm \mathrm{SEM}$.

The fluid intake was similar in all three groups, but the higherdose hMSC-treated sheep had numerically more urine output. The differences in fluid balance were not statistically significant.

\section{Chemistry measurements}

There were no differences in the serum BUN, creatinine, ALT, lactate or glucose among the three groups at baseline, 12 or $24 \mathrm{~h}$ (table 2). Serum AST was significantly lower in the sheep treated with lower dose hMSCs vs control sheep $(p=0.03)$.

\section{Oxygenation}

The control sheep developed severe hypoxaemia that progressed throughout the experimental period; at $24 \mathrm{~h}$ the $\mathrm{PaO}_{2} / \mathrm{FiO}_{2}$ ratio was $97 \pm 15 \mathrm{~mm} \mathrm{Hg}$ (figure 5). In the 15 sheep that remained alive at the $24 \mathrm{~h}$ time point, the $\mathrm{PaO}_{2} / \mathrm{FiO}_{2}$ ratio was significantly higher in both hMSC-treated groups compared

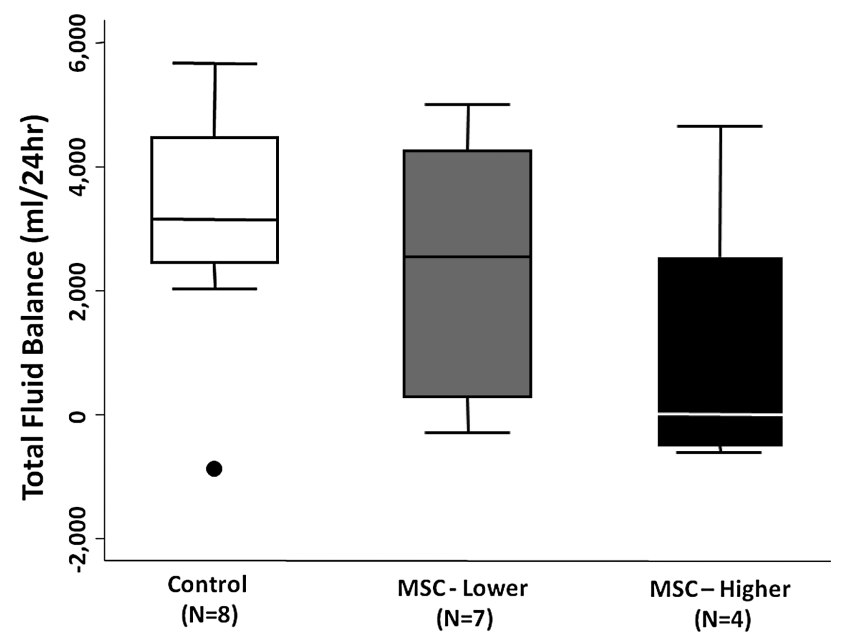

Figure 4 Total fluid balance (fluid in-urine output) in $\mathrm{mL}$ over the $24 \mathrm{~h}$ period in sheep treated with PlasmaLyte A alone (control) $(n=8)$, lower-dose hMSCs $\left(5 \times 10^{6}\right.$ cells $\left./ \mathrm{kg}\right)(\mathrm{n}=7)$ and higher-dose hMSCs $\left(10 \times 10^{6}\right.$ cells $\left./ \mathrm{kg}\right)(\mathrm{n}=4)$. There were no differences among the three groups by Kruskal-Wallis equality-of-populations rank test. Data are expressed as median with $25-75 \%$ centiles. with the control group (lower dose: $288 \pm 55 \mathrm{~mm} \mathrm{Hg}$ $(\mathrm{P}=0.003)$; higher dose: $327 \pm 2 \mathrm{~mm} \mathrm{Hg}(\mathrm{P}=0.003)$ ) (figure 5). The $\mathrm{PaO}_{2} / \mathrm{FiO}_{2}$ ratios in both the lower-dose and higher-dose hMSC groups were also numerically higher than in the control group over the $24 \mathrm{~h}$ period; this difference almost reached statistical significance $(\mathrm{p}=0.07$ and $\mathrm{p}=0.053$, respectively).

Bronchoalveolar lavage fluid bacterial and neutrophil counts There were no differences in the median number of bacteria in control sheep or in the number of neutrophils (see online supplementary material).

Table 2 Serum measures of kidney and liver function, glucose and lactate in the three groups of sheep at baseline, 12 and $24 \mathrm{~h}$

\begin{tabular}{|c|c|c|c|c|}
\hline Parameter & Group & Baseline & 12 & 24 \\
\hline Blood urea nitrogen & $\begin{array}{l}\text { Control } \\
\text { Lower dose } \\
\text { Higher dose }\end{array}$ & $\begin{array}{l}13 \pm 1 \\
13 \pm 1 \\
16 \pm 4\end{array}$ & $\begin{array}{l}11 \pm 2 \\
14 \pm 2 \\
14 \pm 3\end{array}$ & $\begin{array}{l}15 \pm 4 \\
13 \pm 1 \\
10 \pm 2\end{array}$ \\
\hline Creatinine & $\begin{array}{l}\text { Control } \\
\text { Lower dose } \\
\text { Higher dose }\end{array}$ & $\begin{array}{l}0.6 \pm 0.0 \\
0.7 \pm 0.0 \\
0.7 \pm 0.0\end{array}$ & $\begin{array}{l}0.7 \pm 0.1 \\
1.0 \pm 0.2 \\
0.8 \pm 0.1\end{array}$ & $\begin{array}{l}0.9 \pm 0.1 \\
0.9 \pm 0.2 \\
0.7 \pm 0.1\end{array}$ \\
\hline Alanine transaminase & $\begin{array}{l}\text { Control } \\
\text { Lower dose } \\
\text { Higher dose }\end{array}$ & $\begin{array}{l}46 \pm 4 \\
46 \pm 7 \\
57 \pm 7\end{array}$ & $\begin{array}{l}40 \pm 2 \\
42 \pm 6 \\
53 \pm 6\end{array}$ & $\begin{array}{l}39 \pm 3 \\
39 \pm 5 \\
43 \pm 6\end{array}$ \\
\hline Aspartate aminotransferase & $\begin{array}{l}\text { Control } \\
\text { Lower dose } \\
\text { Higher dose }\end{array}$ & $\begin{array}{l}177 \pm 20 \\
161 \pm 27 \\
200 \pm 26\end{array}$ & $\begin{array}{l}160 \pm 24 \\
135 \pm 23 \\
195 \pm 33\end{array}$ & $\begin{array}{l}187 \pm 22 \\
140 \pm 16 * \\
143 \pm 12\end{array}$ \\
\hline Glucose & $\begin{array}{l}\text { Control } \\
\text { Lower dose } \\
\text { Higher dose }\end{array}$ & $\begin{array}{l}70 \pm 4 \\
65 \pm 3 \\
59 \pm 6\end{array}$ & $\begin{array}{l}38 \pm 5 \\
45 \pm 4 \\
35 \pm 3\end{array}$ & $\begin{array}{l}37 \pm 4 \\
34 \pm 2 \\
33 \pm 4\end{array}$ \\
\hline Lactate & $\begin{array}{l}\text { Control } \\
\text { Lower dose } \\
\text { Higher dose }\end{array}$ & $\begin{array}{l}0.5 \pm 0.1 \\
0.3 \pm 0.0 \\
0.4 \pm 0.1\end{array}$ & $\begin{array}{l}3.7 \pm 1.3 \\
3.2 \pm 0.6 \\
2.8 \pm 1.0\end{array}$ & $\begin{array}{l}2.2 \pm 0.7 \\
2.4 \pm 1.0 \\
1.4 \pm 0.1\end{array}$ \\
\hline \multicolumn{5}{|c|}{$\begin{array}{l}\text { Data are expressed as } \pm \text { SEM. No differences at baseline by one-way ANOVA, and at } \\
12 \mathrm{~h} \text { and } 24 \mathrm{~h} \text { by ANCOVA among three groups except indicated. Baseline: } n=8 \text { for } \\
\text { control; } n=7 \text { for lower dose; } n=4 \text { for higher dose. } T=12 h: n=8 \text { for control; } n=6 \text { for } \\
\text { lower dose; } n=4 \text { for higher dose. T=24 h: } n=6 \text { for control; } n=6 \text { for lower dose; } n=3 \\
\text { for higher dose. } \\
{ }^{*} p=0.03 \text { by ANCOVA compared with control group. }\end{array}$} \\
\hline
\end{tabular}




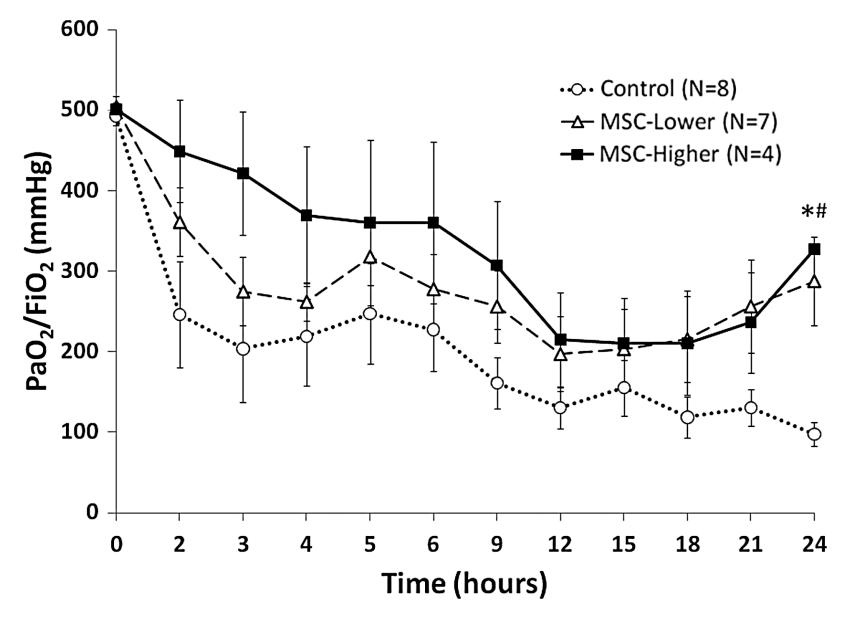

Figure 5 The $\mathrm{PaO}_{2} / \mathrm{FiO}_{2}$ ratio $(\mathrm{mmHg})$ in sheep treated with PlasmaLyte $A$ alone (control) (T0: $n=8 ;$ T24: $n=6$ ), lower-dose hMSCs $\left(5 \times 10^{6}\right.$ cells/kg) (T0: $n=7 ;$ T24: $\left.n=6\right)(n=7)$ and higher-dose hMSCs $\left(10 \times 10^{6}\right.$ cells/kg) (T0: $\left.n=4 ; T 24: n=3\right)(n=4) .{ }^{*} p=0.003$ in higher-dose hMSC-treated sheep compared with control sheep by ANCOVA at $24 \mathrm{~h}$. ${ }^{\#} \mathrm{p}=0.003$ in lower-dose $\mathrm{hMSC}$-treated sheep compared with control sheep by ANCOVA at $24 \mathrm{~h}$. There were no significant differences among treatment groups over the $24 \mathrm{~h}$ period by the GEE. Data are expressed as mean \pm SEM.

\section{Postmortem extravascular lung water}

Lung water content was lower in the higher-dose hMSC-treated group (median=5.0 g wet/g dry [IQR 4.9-5.8]) compared with the control group (median=6.7 g wet/g dry [IQR 6.4-7.5]) $(p=0.01)$. There was no statistical difference in lung water content in the lower-dose hMSC-treated group compared with the control group $(p=0.73)$ (figure 6).

\section{DISCUSSION}

There were two primary objectives of this preclinical large-animal sheep study. The first was to test the safety of hMSCs in critically ill sheep with ALI. The second was to test

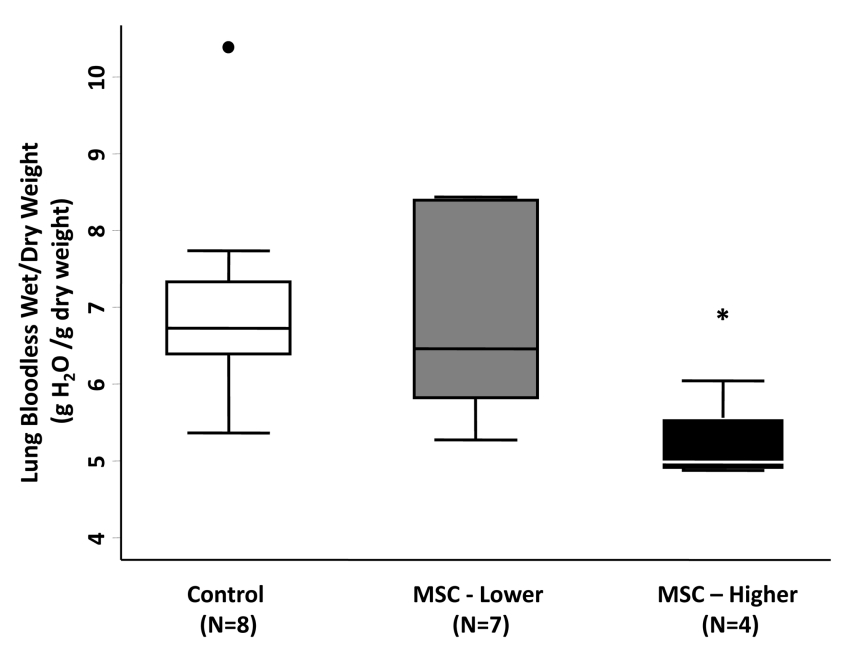

Figure 6 Postmortem lung bloodless wet/dry weight ratio in sheep treated with PlasmaLyte A alone (control) $(n=8)$, lower-dose hMSCs $\left(5 \times 10^{6}\right.$ cells $\left./ \mathrm{kg}\right)(\mathrm{n}=7)$ and higher-dose hMSCs $\left(10 \times 10^{6}\right.$ cells $\left./ \mathrm{kg}\right)(\mathrm{n}=4)$. ${ }^{*} p=0.01$ in higher-dose hMSC-treated sheep compared with control group by Mann-Whitney rank-sum test with Bonferroni adjustments. Data are expressed as median with $25-75 \%$ centiles. the efficacy of hMSCs in the treatment of ALI with the primary focus on lung fluid balance and oxygenation, and to determine whether there were any significant differences between a lower and a higher dose of hMSCs. Both doses of hMSCs were well tolerated. Both doses of hMSCs were associated with improved oxygenation $\left(\mathrm{PaO}_{2} / \mathrm{FiO}_{2}\right)$ at $24 \mathrm{~h}$, and the higher dose of hMSCs decreased the quantity of postmortem pulmonary oedema. These results provide the foundation for translation to test hMSCs in critically ill patients with moderate-to-severe ARDS in a phase $1 / 2$ clinical trial. ${ }^{22}$

We and other investigators have completed several preclinical studies in small animal models, as well as studies in an ex vivo perfused human lung preparation. Prior to this study, however, there had been no clinically relevant studies of hMSCs in a large animal model of ALI. This model is analogous to the clinical setting because the sheep were managed as if they were in an intensive care unit; three investigators stayed with the sheep at all times throughout the $24 \mathrm{~h}$ time period, adjusting the ventilator settings and fluid administration, and monitoring haemodynamics, gas exchange and several other variables. Additionally, the sheep received positive pressure ventilation and PEEP, similar to patients with ARDS. Thus, multiple features allowed by this large animal model make it more a more relevant comparison to human patients with ARDS; most of these features simply cannot be replicated in small animals or in the ex vivo perfused human lung.

Equally important, the sheep model made it possible to measure several clinically relevant physiological endpoints for both pulmonary and systemic circulation, and to obtain laboratory data regarding kidney function, liver function, and acid base status. Finally, we were able to measure peak and pause (plateau) airway pressure, as well as to obtain postmortem data on the quantity of pulmonary oedema, adding to our ability to test for safety and efficacy.

The testing of hMSCs in critically ill large animals with ALI for safety is perhaps most important. The safety record of hMSCs in several clinical trials has been excellent, but we wanted to determine whether intravenous administration of hMSCs would result in a significant increase in pulmonary arterial pressure (an effect that could decrease in right ventricular stroke volume and cause systemic hypotension). The results demonstrate that there were no differences in pulmonary vascular resistance, cardiac output or systemic vascular resistance among the three groups. In particular, mean pulmonary arterial pressure was significantly lower at $24 \mathrm{~h}$ in both the lower-dose and higher-dose hMSC-treated sheep compared with the control sheep. Thus, hMSCs did not compromise pulmonary haemodynamics and may have even exerted a favourable effect on the acutely injured pulmonary circulation. Similarly, the systemic arterial pressure was higher at $24 \mathrm{~h}$ in the higher-dose hMSC-treated sheep compared with the control and lower-dose hMSC-treated sheep, suggesting no deleterious effect of hMSCs on systemic haemodynamics, and potentially a favourable effect on systemic blood pressure with the higher hMSC dose. Taken together, these results provide some reassurance that testing of this cell-based therapy in patients with moderate-to-severe ARDS is warranted in terms of anticipated tolerability.

In regards to efficacy, oxygenation was significantly improved at $24 \mathrm{~h}$ in the sheep treated with either dose of hMSCs compared with the controls. There was also a trend for oxygenation to be higher in both hMSC-treated groups throughout the entire $24 \mathrm{~h}$ period, although this trend did not achieve statistical significance. Additionally, the postmortem measurement of extravascular lung water (a standard measure for the quantity of 
pulmonary oedema) showed a significant decrease in sheep treated with the higher dose of hMSCs. Although both doses were effective in improving oxygenation, the evidence that extravascular lung water was significantly reduced in the higherdose hMSC group provides a rationale for making the higher dose $\left(10 \times 10^{6}\right.$ cells $\left./ \mathrm{kg}\right)$ the target dose for testing tolerability and efficacy in a clinical trial of hMSCs for ARDS.

There are several limitations to this study. First, this study of ALI in sheep models only the first $24 \mathrm{~h}$ of human ARDS. Logistically it was not possible to sustain this model for more than $24 \mathrm{~h}$. Second, it will not be possible to administer hMSCs in the clinical setting of ARDS within $1 \mathrm{~h}$ of injury to the lung. Thus, when tested in patients, the time window for treatment after ARDS develops will be longer. Third, although the sheep model includes the lung physiologic abnormalities that occur in patients with ARDS, and also replicates some of the process-of-care variables (positive pressure ventilation and intravenous fluid administration), it does not reflect the comorbidities that complicate the course of many patients with ARDS (eg, diabetes, immunosuppression and advanced age). Moreover, we did not test the effect of antibiotics in this model, although we have recently reported the differential effect of antibiotics and hMSCs in our ex vivo perfused human lung experiments. ${ }^{14}$ Finally, although investigators were not aware of the treatment arm to which sheep would be assigned before injury, they were not blinded to treatment group after injury.

In summary, administration of hMSCs in sheep with severe lung injury demonstrated no safety issues. Moreover, there was evidence of efficacy in terms of improved oxygenation with either dose of hMSCs, and a decrease in the quantity of pulmonary oedema in the sheep treated with the higher dose of hMSCs. Based on these results, our plan is to proceed to clinical testing of allogeneic bone marrow-derived hMSCs in patients with moderate-to-severe ARDS with an FDA-reviewed clinical trial $^{22}$

Acknowledgements This work was supported by NIH Grant GM097480-01A1 (PE), and Shriners Hospital of North America Grants SHC85500 (PE) \& 84050 (DLT). Clinical grade, cryopreserved human allogeneic MSCs were obtained from an $\mathrm{NIH}$-supported Production Assistance for Cellular Therapies group (Molecular and Cellular Therapeutics, UMN), Contract \# HHSN268201000008C. We want to acknowledge the major contributions of both Dr Traber and his wife, Lillian Traber, both of whom have passed away since these experiments were completed.

Contributors SA: collection and/or assembly of data, data analysis and manuscript writing; HI: surgical procedures, collection and/or assembly of data and data analysis; DLT: study conception and design, financial support, data analysis and interpretation; JWL: design of the experiments, preparation of the mesenchymal stem cells, interpretation of the results and manuscript writing; RAC and HKH: design, data analysis and manuscript editing; DFM: design of the experiments, data interpretation and manuscript writing; DHM: preparation of the mesenchymal stem cells, interpretation of the results and manuscript writing; LDT: surgical procedures and experimental design; $\mathrm{HZ}$ : data entry, statistical analyses of all the data, manuscript and figure preparation; JW: manuscript writing and editing, and composition of the tables; DNH: concept development and study design; DSP: concept development, study design and data interpretation; KDL: experimental design, data interpretation and manuscript editing; MAM: experimental design, data analysis, data and table organisation, and manuscript writing; PE: experimental design, surgical procedures, data analysis and interpretation, financial support, concept development, manuscript writing and responsible for overall content as guarantor.

Competing interests None.

Provenance and peer review Not commissioned; externally peer reviewed.

\section{REFERENCES}

1 Matthay MA, Ware LB, Zimmermann GA. The acute respiratory distress syndrome. J Clin Invest 2012;122:2731-40.

2 Ware LB, Matthay MA. Acute respiratory distress syndrome. N Engl J Med 2000;342:1334-49.

3 Eisner MD, Thompson T, Hudson LD, et al. Efficacy of low tidal volume ventilation in patients with different clinical risk factors for acute lung injury and the acute respiratory distress syndrome. Am J Respir Crit Care Med 2001;164:231-6.

4 ARDS definition task force. Acute respiratory distress syndrome: the Berlin Definition. JAMA 2012;307:2526-33.

5 Amato MB, Barbas CS, Medeiros DM, et al. Effect of a protective-ventilation strategy on mortality in the acute respiratory distress syndrome. N Engl J Med 1998;338:347-54.

6 Guerin C, Reignier J, Richard JC, et al. Prone positioning in severe acute respiratory distress syndrome. N Engl J Med 2013;368:2159-68.

7 Wiedemann HP, Wheeler AP, Bernard GR, et al. Comparison of two fluid-management strategies in acute lung injury. $N$ Engl I Med 2006;354:2564-75.

8 Iso Y, Spees JL, Serrano C, et al. Multipotent human stromal cells improve cardiac function after myocardial infarction in mice without long-term engraftment. Biochem Biophys Res Commun 2007;354:700-6.

9 Lee RH, Seo MJ, Reger RL, et al. Multipotent stromal cells from human marrow home to and promote repair of pancreatic islets and renal glomeruli in diabetic NOD/scid mice. Proc Natl Acad Sci USA 2006;103:17438-43.

10 Nemeth K, Leelahavanichkul A, Yuen PS, et al. Bone marrow stromal cells attenuate sepsis via prostaglandin E2-dependent reprogramming of host macrophages to increase their interleukin-10 production. Nat Med 2009;15:42-9.

11 Parekkadan B, van Poll D, Suganuma K, et al. Mesenchymal stem cell-derived molecules reverse fulminant hepatic failure. PLoS ONE 2007;2:e941.

12 Togel F, Hu Z, Weiss K, et al. Administered mesenchymal stem cells protect against ischemic acute renal failure through differentiation-independent mechanisms. Am J Physiol Renal Physiol 2005;289:F31-42.

13 Lee JW, Fang X, Krasnodembskaya A, et al. Mesenchymal Stem Cells for Acute Lung Injury: Role of Paracrine Soluble Factors. Stem Cells 2011;29:913-19.

14 Lee JW, Krasnodembskaya A, McKenna DH, et al. Therapeutic effects of human mesenchymal stem cells in ex vivo human lungs injured with live bacteria. Am J Respir Crit Care Med 2013;187:751-60.

15 Krasnodembskaya A, Samarani G, Song Y, et al. Human mesenchymal stem cells reduce mortality and bacteremia in gram-negative sepsis in mice in part by enhancing the phagocytic activity of blood monocytes. Am J Physiol Lung Cell Mol Physiol 2012;302:L1003-13.

16 Gupta N, Krasnodembskaya A, Kapetanaki M, et al. Mesenchymal stem cells enhance survival and bacterial clearance in murine Escherichia coli pneumonia. Thorax 2012;67:533-9.

17 Rehberg S, Yamamoto Y, Sousse $L E$, et al. Antithrombin attenuates vascular leakage via inhibiting neutrophil activation in acute lung injury. Crit Care Med 2013;41: e439-46.

18 Lange M, Hamahata A, Traber DL, et al. Pulmonary microvascular hyperpermeability and expression of vascular endothelial growth factor in smoke inhalation- and pneumonia-induced acute lung injury. Burns 2012;38:1072-8.

19 Murakami K, Bjertnaes LJ, Schmalstieg FC, et al. A novel animal model of sepsis after acute lung injury in sheep. Crit Care Med 2002;30:2083-90.

20 Enkhbaatar $\mathrm{P}$, Lange $\mathrm{M}$, Nakano $\mathrm{Y}$, et al. Role of neuronal nitric oxide synthase in ovine sepsis model. Shock 2009;32:253-7.

21 Pearce ML, Yamashita J, Beazell J. Measurement of pulmonary oedema. Circ Res 1965;16:482-8.

22 NCT01775774. Human mesenchymal stem cells for acute respiratory distress syndrome (START). http://clinicaltrials.gov/show/NCT01775774 